HERMINA CIELAS

(1) HTTP://ORCID.ORG/ 0000-0002-4709-3043

Jagiellonian University

e-mail: hermina.cielas@gmail.com

\title{
Poetry at the Threshold. A.R. Rajaraja Varma and the New Sanskritism
}

\begin{abstract}
A.R. Rajaraja Varma (A.R. Rājarājavarmma, 1863-1918), a Kerala poet, grammarian and critic witnessed the late $19^{\text {th }}$ and early $20^{\text {th }}$ century evolution of South Indian literature and actively participated in the changes. His unique relationship with languages, great knowledge of grammar, poetic talent and a leaning towards a modern approach (to a large extent affected by English) resulted in various works which influenced the development of both Sanskrit and Malayalam. Rajaraja Varma strove to modernise Indian languages and literature, largely by the means of more innovative English. The unusual blend of styles, themes, and motives that interweave in the author's compositions can be defined as the New Sanskritism. The aim of this paper is to distinguish characteristic features of Rajaraja Varma's Sanskrit works and discuss them in their socio-cultural context.
\end{abstract}

Keywords: Rararaja Varma, Sanskrit, Malayalam, New Sanskritism

India's literary output has always been influenced by the multilingualism of the subcontinent. Vernacular languages had to face linguistic imperialism. In $19^{\text {th }}$ century, for their users, both Sanskrit (the carrier of culture and heritage on a nationwide level) and hegemonic English standing in opposition, were a linguistic embodiment of the superior power. British imperialism was perceived as more detrimental due to its exterior origin but for many people Sanskrit was not the first choice for expressing cultural identity either. The influence of vernacular nationalists was especially strong in states where non-hegemonic languages had a well-established literary tradition, e.g. Kerala, Tamil Nadu. Despite their need for complete independence, the coexistence of languages resulted in an inevitable exchange. According to Hardy, Sanskrit literature used vernaculars when it was useful, and took over and transformed some themes, while vernaculars, thanks to 
Sanskrit loanwords and poetics, could accomplish what seemed impossible for a living language to achieve. ${ }^{1}$

Three streams of influences - indigenous, Tamil, and Sanskrit (the last two more developed) - can be discerned in the formative stage of literary Malayalam. ${ }^{2}$ Moreover, the $18^{\text {th }}-19^{\text {th }}$ centuries Malayalam with already well-established prominence had to coexist with English due to the political situation. The nonindigenous influences are usually perceived as negative, but should not be understood as thoroughly detrimental since were, in this case, the trigger for innovation and literary dispute. The venmaniprasthannam, a movement of linguistic extremists propagating so-called pure Malayalam devoid of Sanskritism, was countered by proponents of the opposite tendency, known as the Travancore poets. ${ }^{3}$ But in between there was a threshold, a trend which can be defined as the New Sanskritism $^{4}$, aimed at the revival of Sanskrit literature in a modern style, accessible for a larger group of people. It was a blend of both radical tendencies, choosing what was the best in them. It was not only aimed at creating works which duplicate classical forms and versification of Sanskrit literature. This function was played by the Travancore poets. The advocates of moderate trend used Sanskrit as a tool which can be modernised and made suitable for compositions addressing contemporary themes. But the mechanism was not the same as in the case of venmaniprasthānam characterized by incorporating Sanskrit elements only when necessary, overloading it with the erotic and humour, simplifying the text's form and content. The idea of what we can address nowadays as the New Sanskritism was to adjust the language in such a way that it would be able to express everything, not only humorous content, it would be understandable to the modern reader but not overly simplified, and finally, it would be used as a medium in the creation of new genres.

This attitude reflects in the works of Rajaraja Varma (A.R. Rājarājavarmma, 1863-1918). ${ }^{5}$ He left a vast literary legacy in Malayalam, Sanskrit, and English characterised by the harmonious exchange between the languages and leaning towards non-obvious, new solutions. The choice of linguistic means was

1 F. Hardy, Give and Take: Sanskrit Poetry in Context [in:] Sanskrit Literature, ed. A.N.D. Haksar, New Delhi 1995, p. 157.

2 K.M. George, Makers of Indian literature. A.R. Rajaraja Varma, New Delhi 1979, p. 9.

3 See e.g. S.K. Das, A History of Indian Literature 1800-1910: Western Impact: Indian Response, New Delhi 2000, K.M. George, A Survey of Malayalam Literature, London 1968, pp. 139-142, A.S. Menon, A Survey of Kerala History, Chennai 2006, pp. 421-429. E. Nampoothiry, Sanskrit Literature of Kerala: Index of Authors with Their Works, Trivandrum 1972, contains a list of Kerala authors and their Sanskrit works.

${ }^{4}$ I propose the term New Sanskritism instead of the maybe more intuitive Neo-Sanskritism because the latter occurs in linguistics to indicate the words coined out of Sanskrit for modern usage.

5 The full name-A.R. Rājarājavarmma Kōiltampurān - underlines poet's position in high Kerala society. Köil refers to royalty or temples and tampurān is a term of respect. Rajaraja Varma was a poet, educator, grammarian, critic, and practitioner of akșaraśloka based on the traditional way of śloka chanting (K.M. George, Makers..., p. 18). More on the akșaraśloka in L. Sudyka, C. Galewicz, If you Know One Thousand Śloka-s, You Are Half a Poet: On the Akșara-śloka Traditions of Kerala, "Cracow Indological Studies" 2005, vol. 7, pp. 295-315. 
not coincidental. Rajaraja Varma belonged to the closely related to the royalty Kōiltampurān family and received a thorough education. His father, Vāsudevam Nambūdiri, was a scholar proficient in the Vedas and astrology. Rajaraja Varma was taught Sanskrit by the teachers of royal family at the young age. Soon after he received an education in the field of poetry and astrology. When the family moved to Haripād his illustrious uncle, Kerala Varma (Kēralavarmma Valiya Kōiltampurān; 1845-1914), taught him English, Mathematics and History. ${ }^{6}$ Taking into consideration the milieu in which Rajaraja Varma grew up, his scholarship, close relationship with the royalty and poetic circles and the coeval political situation of India, it does not surprise that he wrote in Malayalam, Sanskrit and English. He was deeply anchored in classical Indian literature but Malayalam was his mother tongue, intuitive medium of poetical expression. The third route, the Western literature accessible via English, also influenced him greatly. As noticed by Subramanian "Shakespeare was a passion, Freud was a love, Lord Macaulay was an appetite, Walter Scott and Thackeray were enchantments to him".?

Rajaraja Varma's Sanskrit works contain surprising elements untypical for the literature in this language. The author was aware of the strengths and weaknesses of individual resources:

Rajaraja Varma [...] was for an assimilation of what is best in both [Western and Eastern literature - HC]. [...] Poetry in Malayalam had a longer tradition than prose and hence there was justification in leaning more towards Sanskrit poetics and prosody as far as verse composition was concerned. [...] However, prose in Malayalam would benefit considerably by leaning towards English both in form and content. ${ }^{8}$

Indeed, among the poet's early works are more ornate creations, e.g. Citranakșatramālā (The garland of picturesque stars, 1880), joining the traditional form - a laudatory poem in citra style $^{9}$ - with contemporary theme - rules of the author's patron and mahārāja of Travancore, Visakham Tirunal (Viśākham Tirunāl Mahārāja), described as

virottamsakșițiśāyutamakuța ghațatpādavikșobhitāre

suśronīiśren̄icitta avasathadamada mūrtiprayuktāva[em.; pa $]^{10}$ māda |

pādātākșinnapāṇīsadanada parahr ttāpatīvrārtisoma

śrīvañcikṣoṇipālo raṇaratasuguṇaśrenipūra praroha || CNM 21.

6 The account of Rajaraja Varma's education is based on K.H. Subramanian, Kerala Panini and Sanskrit works, Delhi 2008, pp. 21-25.

7 Ibid., p. 27.

K.M. George, Makers..., p. 40.

9 The poem's twenty-seven stanzas replete with verbal juggleries - citras -such as: vargarahitas - stanzas deprived of certain syllables; ekā- or dvyakșaras - with only one or two syllables; and bandhas - passages, which can be re-written in the shape of objects. Citrakāvyas can be divided based on the criterion of the figure's function: didactic (didactic literature and literary games' collections), semantic (narrative poems) and laudatory (poems of praise). They differ in terms of forms, level of their difficulty and artistic value. Citranakșatramālā belongs to the last type, represented mostly by religious panegyrics, like Ānandavardhana's Devīśataka or Avātara's İśvaraśataka. For more on the work see H. Cielas, The Implementation of the Pan-Indian form on the Keralan Ground: A.R. Rajaraja Varma’s Citranakșatramālā, "Cracow Indological Studies" 2016, vol. 18, pp. 255-257.

10 The visual pattern justifies choosing $v a$ as the correct sound in this position. 
The one [adorned] with a king's diadem combined with a hero's garland, the one who makes enemies' legs tremble, [filled with] the number of thoughts concentrated on the goddess, giving punishment and abode, having the favour of being united with the idol, embodied passion ${ }^{11}$, effecting exhaustion of not drooping hands of infantry, the nectar removing burning, excruciating pain of others, the protector of glorious land of Vañci, filled with the mass of extraordinary fondness for the fight. Arise!

Like the other most complicated citras the stanza mostly consists of vocative forms. The lack of more complex case-endings facilitates matching of the text with its visual pattern, here, nāgabandha, the serpent pattern. ${ }^{12}$

Other Sanskrit compositions by Rajaraja Varma - a one-act play, a prose passage and twelve short poems ${ }^{13}$ - mostly composed at the end of the $19^{\text {th }}$ century, can be found in Sähityakutūhala (1904). They played the role of samples presenting different genres or kinds of versification. The author followed various sources of inspiration. The take off and the flight of a balloon conducted in Madras by an English man called Spencer, resulted in the ex-tempore verses, known as Vimānāstakam, Eight verses on the aerial vehicle (1891), incorporating more interesting topics for a modern reader of Sanskrit poetry. ${ }^{14}$

Looking for unusual solutions, Rajaraja Varma paid tribute to English literature by composing a poem based on Shakespeare's Othello. ${ }^{15}$ Uddālacaritam, The adventures of Uddāla (1898) ${ }^{16}$, described by George among Rajaraja Varma's translations ${ }^{17}$, is a prose composition inspired rather by Lamb's Tales from Shakespeare than by the original. In the author's opinion it served

as an exercise for the English reading student to whom Sanskrit is fast growing to be more alien than a foreign tongue, and partly as a means of a tongue conveying to the mind of the orthodox Pandit some idea of the marvellous creative imagination of the Western Poet. ${ }^{18}$

Rajaraja Varma modified the characters' names to make it more intelligible and suitable for Sanskrit pronunciation ${ }^{19}$ and included well-known motives. ${ }^{20}$

11 Mãda, embodied passion, refers also to being intoxicated, engulfed by the battle frenzy.

12 For details on nāgabandha's formation see H. Cielas, op. cit., pp. 255-257.

13 K.H. Subramanian, op. cit., p. 35. George mentions seven works included in Sāhityakutūhala (K.M. George, Makers..., pp. 49-50) while Nampoothiry enumerates fourteen (E. Nampoothiry, op. cit., pp. 86-87).

14 K.H. Subramanian, op. cit., p. 40.

15 Sanskrit renditions of Shakespeare started to appear at the end of the $19^{\text {th }}$ century in Sahridaya, the South Indian Sanskrit magazine (V. Raghavan, Shakespeare in Sanskrit, "Indian Literature" 1964, vol. 7[1], p. 110). Rajaraja Varma's work was also preceded by the S. Dikshita's Bhrāntivilāsa (1877's Sanskrit version of The Comedy of Errors) and R. Krishnamachari's Vasantikāsvapna (1892), rendering A Midsummer Night's Dream (ibid., p. 114). For more see N. Bhatia, "Shakespeare" and the Codes of Empire in India, "Journal of Comparative Poetics" 1998, vol. 18, pp. 96-126 or A. Loomba, Shakespeare, Race, and Colonialism, Oxford 2002.

16 Alternatively called Uddālakacaritam (E. Nampoothiry, op. cit., p. 87; K. Kunjunni Raja, The Contribution of Kerala to Sanskrit Literature, Madras 1980, p. 257).

17 K.M. George, Makers..., p. 48.

18 A.R. Rajaraja Varma, Sāhitya Kutūhalam. A collection of minor works by A.R. Raja Raja Varma, ed. R. Narayana Sastral, Trivandrum 1925, p. 1.

19 E.g. Othello became Uddāla, Desdemona turned into Doșadamanā, and Iago into Ayāga.

20 E.g. juxtaposing the reaction of Balarāma to Subhadrā and Arjuna's marriage (from the first book of Mahäbhārata) with Brabantio's reaction to Desdemona's marriage to Othello. 
Sanskrit ornate style seemed to be the best tool for rendering Early Modern English literature, for both languages played the role of a sophisticated carrier of classical literature.

The love for English culture was also expressed in the author's longest work, Ängalasāmräjya, The British Empire (completed in 1900, published in 1901), a historical mahākāvya with twenty-three sargas. ${ }^{21}$ It was composed on advice of Kerala Varma ${ }^{22}$, on the occasion of Queen Victoria's Diamond Jubilee. $\bar{A} \dot{n} g a l a s a \bar{m} r a \bar{j} y a$ abounds with comparisons between Indian and Western culture ${ }^{23}$, allusions to such events as Caesar's crossing of the Rubicon (ĀS 6.65), numerous neo-sanskritisms and sanskritized English proverbs, like bhraștāt paribhrașta ivāgnikunde (ĀS 13.58, "as to fall into the fireplace from being ruined", an equivalent of "from the frying pan into the fire"). Rajaraja Varma aimed to create something traditional but adapted to a modern theme, like in the description of London:

\section{sadaiva nānāvidhaśilpaśālāpraṇālamārgena vinirgaladbhị̣| \\ dhūmapratānaih śaradāgame 'pi yatrābhraliptīva virājati dyauh $\| \bar{A} S 1.2$ \\ $[\ldots]$ \\ yatrāgniyānāni surūngikābhirvīthị̦̣v adhastāl laghu paryațanti | \\ gṛaprañālodarakheladākhuviceștitānìva viḍambayanti \| \\ dhümaì vamantah śikhinam gilanto vetālavīrā iva yantrarājāh \\ śilpāni yatrādbhutadușkarāṇi niṣpādayanti śramam antareṇa $\| \bar{A}$ S 1.8-9.}

Because of the diffuseness of smoke flowing away through the chimneys of various industrial buildings, the sky always looks like it is covered with clouds in the proximity of autumn.

$[\ldots]$

Whereas the trains quickly meander about from below through underground passages towards the roads as if they mock, similar to rats which, set in motion, create shaking inside the pipes of the house.

Where contrivances, such as the kings of engines vomiting smoke and swallowing flames, like heroic demons, marvellous and difficult to create, bring about weariness at the same time. $^{24}$

The poet created the industrial London's image by using neologisms connected to technological progress, as śilpaśäläpraṇāla ("the channel of a workshop", chimney), agniyāna ("the fire wagon", train), grhapranālodara ("the abdomen of the channels of the house", inside the pipes of the house), which resulted in more poetic description.

Rajaraja Varma chose Sanskrit for Āंngalasāmrājya intentionally: “[...] none of the Indian vernaculars is expected to be understood - far less appreciated -

${ }^{21}$ On the mahākāvya genre, see e.g. S. Lienhard, A History of Classical Poetry: Sanskrit-PaliPrakrit, Wiesbaden 1984, pp. 159-227. For the work's detailed study and a short review of Sanskrit works on the British Empire in India see K.H. Subramanian, op. cit.

22 Ibid., p. 121.

23 E.g. the Governor-General of India (1798-1805), Richard Wellesley, was compared to Indropama and James Broun-Ramsay, known as The Earl of Dalhousie (1838-1849), to Dharmaputra ("the son of dharma", a term describing Yudhișțira). See ibid., p. 166.

${ }^{24}$ All the emendations and translations from Sanskrit quoted in the article are made by its author. 
outside India, while Sanskrit, for its philological value, has secured scholars throughout the civilised world". ${ }^{25} \mathrm{He}$ composed the work on the basis of Sanskrit mahākāvyas, for centuries serving as a laudatory vehicle, and counted on gaining the appreciation of the British suzerains. Nonetheless, there is no evidence of it being noticed by British. Indians, on the other hand, were disappointed with the work's one-sided version. ${ }^{26}$

In 1888, to celebrate the annual day of Sanskrit pāthaśălā, Rajaraja Varma composed the allegorical one-act play Gairvāninvijaya, The victory of Gairvānin. The title character is Sanskrit language, who mourns over her sad lot, gives birth to a child (personified in the Sanskrit journal Vijñana Cintāmani i) and awaits a better time. ${ }^{27}$ Work's aim was to emphasise the dwindling position of Sanskrit and its need for recognition. But Rajaraja Varma did not lose the opportunity to show also the merits of àngali (English); his views were presented as the sages' opinion (Gairvānīvijaya, v. 15). The content of Gairvāninvijaya mirrors the author's attitude towards Sanskrit and English. In the play both languages co-exist, they are not standing in opposition and are supported by the authorities. Mourning Gairvāṇi is consoled by god Brahmā and Garuda, the king of birds, brings her good news of establishing the pāthaśāla in Trivandrum. The same time sages admit the merits of Ängalī. One of them, Durvāsa, has a different opinion - he curses the English language. Nevertheless, soon after he is pacified. In the allegorical way Rajaraja Varma presented the intricacies of current situation of both languages, portrayed various attitudes towards them and in a subtle way showed his own demeanour. The poet fought for Sanskrit's revival but he also appreciated English and its possible contribution to the development of Indian literature. Malayalam took from English the elegy, the ode, the sonnet, and the dramatic monologue. ${ }^{28}$ The elegy was not popular in Indian languages, especially as a separate genre. In the first years of the $20^{\text {th }}$ century, under the influence of British literary laments, many such poems were composed in Malayalam. ${ }^{29}$ Over one decade before, Rajaraja Varma had written two elegies in Sanskrit: Bhangavilappa (The lamentation over failure, 1887), more a poem with a pessimistic tone referring to failure in an examination, and more tragic Pitrpraläpa ${ }^{30}$ (The lamentation of a father, 1893), on the untimely death of his daughter.

Rajaraja Varma played also a role in disputes agitating the Kerala literary milieu at the turn of the century, e.g. so-called (dvitīyākșara)prāsavādam, "controversy over rhyming (the second syllable)". The flashpoint was K.C. Kesava

25 Ibid., p. 122.

26 The author wanted to create historical mahākāvya but as historical sources he used only British works: W.W. Hunter's A History of British India, T.B. Macaulay's Essays on Lord Clive and Warren Hastings, R. Temple's Picturesque India and The 19th Century: A History by Mackenzie (ibid., p. 124).

27 Ibid., p. 45.

28 K.M. George, Western Influence on Malayalam Language and Literature, New Delhi 1972, p. 119.

29 Ibid., pp. $117-118$.

30 Also known as Mãtrpralāpa, The Lamentation of a Mother (E. Nampoothiry, op. cit., p. 86), divided into pitr-, mätr- and ubhayorvacanam, "the speech of father, mother and both". 
Pillai's paper, Bhāṣākavitā (Malayalam poetry). Rajaraja Varma, who perceived the tendency to rhyme the second syllable as "the hallmark of an immature literature" 31 , was cooperating with Kesava Pillai in the public expression of this opinion for the Annual Day of the Malayalam poets' society, Malayāla Samājam, in 1908. The presentation of a paper began an exchange of arguments on the pages of Bhāsāapoṣiṇi, a quarterly named after the Bhāṣā Poṣiṇi Sabhā, the association of poets first known as Kavisamājam established by Kerala Varma and Kandathil Varghese Mappilai (Kanḍattil Vargīs Māppila) in 1892. The conflict lasted for three years, until everyone agreed that Rajaraja Varma, responsible for its escalation, should publish an article "in a spirit of compromise" 32 and although it was never finally resolved, it showed that the number of progressive poets was increasing.

In 1911, when he was already professor of Sanskrit and Dravidian languages $^{33}$, Rajaraja Varma published Sāhityasāhyam (The literary assistant), a manual of Malayalam prose, a guidepost for authors of relatively new genres of literature. Punctuation was only one of its subjects, but it was widely commented upon. Until print started to play a meaningful role in the circulation of literature, thanks to the syntax of the language, Malayalam dealt without the conventional signs or typographical devices in the text. ${ }^{34}$ To remove any possible ambiguity, Rajaraja Varma adopted the English punctuation as a model but introduced it via sanskritized terms. ${ }^{35}$ A few scholars, like H. Gundert or G. Matthan, the authors of works on Malayalam grammar (1859 and 1863), used punctuation marks in this language before, but it was Rajaraja Varma who did it methodically for the first time.

In 1911 Rajaraja Varma wrote the foreword to Nalini, the poem by Kumaran Asan (Kumāran Āśān, 1873-1924), a member of the untouchable Ezhava community ${ }^{36}$ and one of the faces of modernisation. ${ }^{37}$ Rajaraja Varma was blaming the traditional approach and rudiments for the stagnation of Sanskrit and Malayalam which could not reach for new subjects, forms or figures:

The poet, instead of keeping to the beaten track, should let his imagination go into fresh imagery and ideas. [...] a talented author doesn't have to stuff 'the water lily, the moon, the

31 K.M. George, Makers..., p. 60.

32 Ibid., p. 61.

33 According to George (ibid. p. 26), Rajaraja Varma was appointed to the position in 1910. Subramanian claims it happened in 1911 (K.H. Subramanian, op. cit., p. 34).

34 In the Malayalam's conventional structure sentence ends with a finite verb and in the place of commas are specific particles, like um expressing hesitation or a pause in speech.

${ }_{35}$ The list contains, e.g. valayam (bracket), bindu (full-stop), uddharaṇi (quotation mark), kāku (question mark) and vikșepini (exclamation mark). For the complete list see K.M. George, Western Influence..., p. 22.

36 On the Ezhava (or Ilava) community see e.g. C.K. Pullapilly, The Izhavas of Kerala and their Historic Struggle for Acceptance in Hindu Society [in:] Religion and Social Conflict in South Asia, ed. B.L. Smith, Leiden 1976.

37 O.M. Anujan, Movements and institutions: Malayalam [in:] Comparative Indian literature. Vol. II, ed. K.M. George, Trichur 1985, p. 1239. 
bee and the lotus' as similes and metaphors into the texture of his poem, for he can evoke striking images that would be their novelty and freshness. ${ }^{38}$

The new guidance, releasing the poets from the stiff collar of rules, gained the name Rājarājavarmmaprasthānam, "Rajaraja Varma's movement". 39

Rajaraja Varma contributed to the development of Sanskrit and Malayalam from the theoretical and practical points of view, but his life's goal was the growth of the latter. To teach Malayalam meant for him inculcating in his students the basis - especially in the field of poetics to a high degree dependent on Sanskrit and then developing the hitherto knowledge of it. Rajaraja Varma wrote several books on Malayalam and Sanskrit grammar in which he was referring to Pāṇini, the most famous Indian grammarian, other Sanskrit works, Tamil grammar and English sources. It contributed to his most famous nickname - Kēraḷ Pāṇini. ${ }^{40}$ As suggested by George, Rajaraja Varma was influenced by R. Caldwell, the British missionary, author of $A$ Comparative Grammar of the Dravidian or South Indian Family of Languages (1856), and Kéralapāninīyam's title should be changed into Kérala Caldwelliyan. ${ }^{41}$

The poet was trying to fill the gap between classical scholarship and modern language studies. As he claimed

Specialisation in different branches of Sanskrit lore however desirable, in the interests of revival of genuine classical scholarship in India, - is not now common, and following the traditions of the West, the greater number of modern students of Sanskrit desire only such an equipment in grammar and phonetics as would enable them to understand and enjoy the gems of classical Sanskrit literature. ${ }^{42}$

In his works devoted to grammar Rajaraja Varma proved also his versatility in historical and comparative linguistics. The Bhāsācaritra of the second part of Laghupāninīya is focused on the history and general features of the Indo-European family of languages. It includes also some remarks on case-endings and pronouns. His proficiency in the field of historical and comparative linguistics Rajaraja Varma proved also before, e.g. in a short work published as a part of the Sähityakutūhala, titled Hindupadavyutpatti (1890), tracing the etymology of a word "hindu". The thorough knowledge of relations between Indo-European languages and the historical context shaped the author's views and his approach towards the literary creation. Rajaraja Varma understood the mechanisms of the evolution of languages and fully exploited it in his own writings and experiments with literature.

38 A.R. Rajaraja Varma, Foreword to 'Nalini', ed. K.M. George, New Delhi 1992, p. 394.

39 K.M. George, Makers..., p. 63. For the enumeration of differences between the traditional rules on poetry and those proclaimed by Rajaraja Varma, see ibid. or K.M. George, Western Influence..., pp. 115-116.

40 On Malayalam grammar: Kéralapāṇin̄ya (1896), modelled on the Paniniyan pattern; Śabdaśodhin̄ (1902); primary and secondary level compendia - Prathama vyākaraṇa (1905) and Madhyama vyākaraṇa (1907). In Malayalam on Sanskrit grammar: Manidīpika (1909) and Laghupāninīya (the first part 1911, the second, revised, 1917).

41 K.M. George, Makers..., p. 35.

42 A.R. Rajaraja Varma, Laghu-Paniniya. Popular Sanskrit grammar for beginners [LP], Trivandrum 1911, p. 1. 
The poet wanted to align Malayalam with other languages in the spirit of exchange described by Hardy ${ }^{43}$, leading to a harmonious linguistic utopia. But the old order, in which Malayalam writers were referred to as arakkavi, half-poet ${ }^{44}$, although not dominating, was still perceptible. Rajaraja Varma expressed his irritation in the 1914's presidential address prepared for the University of Madras' College Day:

The study of second languages required to be mended, not ended. [...] It (the failure) was not the fault of the languages [...] no fair trial had ever been given to them. In many of the colleges adequate provision had never been made for the efficient teaching of the second languages. The subject was generally entrusted to half-starving, old-fashioned pundits who offered their services for a nominal pay. Consequently the subject lost prestige in the eyes of the students in more ways than one. ${ }^{45}$

In the first years of the $20^{\text {th }}$ century Rajaraja Varma focused more on literary criticism and poetics but he never completely rejected classical Sanskrit forms and diction. In 1912-1918 he also translated several works into Malayalam. The literary output of Rajaraja Varma is rich and heterogenous and it deserves a detailed, critical and evaluative study which, unfortunately, due to the length confinement, lies beyond the scope of present paper. The aforementioned examples of works were presented and briefly described to distinguish characteristic features of Rajaraja Varma's compositions: balanced combination of classical forms and literary devices with new tendencies and mixing local and contemporary themes with pan-Indian motives. They embody the idea of what can be called New Sanskritism - the modernised revivalism of Sanskrit literature influenced by Western languages and Indian vernaculars. This trend mirrored the social and political situation in which lived and created Rajaraja Varma. He was, at the same time, a supporter of British culture and rules in India, a propagator of Sanskrit and a local patriot fighting for the position of Malayalam. Rajaraja Varma, still considered to be one of the greatest poets in the Kerala history, combined these elements with an unusual dynamics, all in a more modern and ecumenic manner.

\section{Bibliography}

Anujan O.M., Movements and Institutions: Malayalam [in:] Comparative Indian literature. Vol. II, ed. K.M. George, Trichur 1985.

Bhatia N. "Shakespeare" and the Codes of Empire in India, "Journal of Comparative Poetics" 1998, vol. 18.

Cielas H., The Implementation of the Pan-Indian form on the Keralan Ground: A.R. Rajaraja Varma's Citranakșatramālā, "Cracow Indological Studies" 2016, vol. 18.

43 F. Hardy, op. cit., p. 157.

44 A depreciating term referring to the poets leaning towards the vernaculars instead of Sanskrit. See e.g. O.M. Anujan, op. cit., p. 1239, or M. Krishnamachariar, History of Classical Sanskrit Literature, Delhi 1989, p. 250.

${ }^{45}$ K. M. George, Makers..., pp. 27-28. 
Das S.K., A History of Indian Literature 1800-1910: Western Impact: Indian Response, New Delhi 2000.

George K.M., A Survey of Malayalam literature, London 1968.

George K.M., Western Influence on Malayalam Language and Literature, New Delhi 1972.

George K.M., Makers of Indian Literature. A.R. Rajaraja Varma, New Delhi 1979.

Hardy F., Give and Take: Sanskrit poetry in Context [in:] Sanskrit Literature, ed. A.N.D. Haksar, New Delhi 1995.

Lienhard S., A History of Classical Poetry: Sanskrit-Pali-Prakrit, Wiesbaden 1984.

Krishnamachariar M., History of Classical Sanskrit Literature, Delhi 1989.

Kunjunni Raja K., The Contribution of Kerala to Sanskrit Literature, Madras 1980.

Loomba A., Shakespeare, Race, and Colonialism, Oxford 2002.

Menon A.S., A Survey of Kerala History, Chennai 2006.

Nampoothiry E., Sanskrit Literature of Kerala: Index of Authors with Their Works, Trivandrum 1972.

Pullapilly C.K., The Izhavas of Kerala and their Historic Struggle for Acceptance in Hindu Society [in:] Religion and Social Conflict in South Asia, ed. B.L. Smith, Leiden 1976.

Raghavan V., Shakespeare in Sanskrit, "Indian Literature” 1964, vol. 7(1).

Rajaraja Varma A.R., Āngalasāmrājyam: Samskrtamahākāvyam [AS], ed. İ. Nampūtiri, Trivandrum 1997.

Rajaraja Varma A.R., Citranakșatramālā [CNM], ed. K.H. Subramanian, Tripunithura 1995.

Rajaraja Varma A.R., Foreword to "Nalini", ed. K.M. George, New Delhi 1992.

Rajaraja Varma A.R., Laghu-Paniniya. Popular Sanskrit Grammar for Beginners [LP], Trivandrum 1911.

Rajaraja Varma A.R., Sāhitya Kutūhalam. A Collection of Minor Works by A.R. Raja Raja Varma [SK], ed. R. Narayana Sastral, Trivandrum 1925.

Subramanian K.H., Kerala Panini and Sanskrit Works, Delhi 2008.

Sudyka L., Galewicz C., If You Know One Thousand Śloka-s, You are Half a Poet: On the Akșara-śloka Traditions of Kerala, "Cracow Indological Studies” 2005, vol. 7. 